\title{
Dynamic Changes in Bacterial Population and Corresponding Exoenzyme Activity in Response to a Tropical Phytoplankton Bloom Chattonella marina
}

\author{
Anit M. Thomas, ${ }^{1}$ M. G. Sanilkumar, ${ }^{2}$ K. C. Vijayalakshmi, ${ }^{1}$ \\ A. A. Mohamed Hatha, ${ }^{1}$ and A. V. Saramma ${ }^{1}$ \\ ${ }^{1}$ Department of Marine Biology, Microbiology and Biochemistry, School of Marine Sciences, \\ Cochin University of Science and Technology, Kochi, Kerala 682 016, India \\ ${ }^{2}$ Post Graduate and Research Department of Botany, SNM College Maliankara, Kochi, Kerala 683 516, India
}

Correspondence should be addressed to Anit M. Thomas; anitmthomas@gmail.com

Received 2 July 2014; Revised 6 September 2014; Accepted 10 September 2014; Published 21 September 2014

Academic Editor: Evgeny Pakhomov

Copyright (C) 2014 Anit M. Thomas et al. This is an open access article distributed under the Creative Commons Attribution License, which permits unrestricted use, distribution, and reproduction in any medium, provided the original work is properly cited.

The raphidophyte Chattonella marina (Subrahmanyan) Hara \& Chihara bloom which causes lethal effects on marine ecosystem has been reported intermittently from Indian waters. In the present study, periodic samplings were made in a Chattonella marina bloom area, off Mahe, on 27 and 29 October and 1 November 2011 (in different phases of the bloom) to assess the associated bacterial population and their exoenzyme activity. Microbial community composition of Chattonella marina bloom revealed a twentyfold increase in bacterial load over the nonbloom area. The bacterial genera, Micrococcus, Flavobacterium, Vibrio, and Pseudomonas, increased significantly during the declining phase of the bloom. An assessment of the extracellular enzyme production also showed a marked increase in percentage of bacterial strains, potent in protease production, suggesting the possible role of proteolytic bacteria in bloom crash. This study reveals the bacterial community succession during the bloom and indicates that bacteria play an important role in bloom regulation.

\section{Introduction}

The marine raphidophycean algae Chattonella marina (Subrahmanyan) Hara \& Chihara have been implicated as one of the toxic HAB species in the world especially in Japan and China [1]. In Indian waters, Chattonella marina bloom has been reported intermittently, along the southwest coast of India $[2,3]$. Faunal mortalities by an ichthyotoxin produced by Chattonella marina bloom have been reported previously [4]. The lack of awareness among the fishermen community in the coastal belt as well as the phenomenon of faunal mortality even though at a low level created an alarming situation in the bloom affected area. Therefore, the need for understanding the role of a biotic regulator of bloom, especially the bacteria, in minimizing the risks associated with such bloom event became important. So far no such reports are available on Chattonella marina bloom. It has been recognized that the interaction between bacteria and algae plays a crucial role in the biology and ecology of the algae and species of harmful algae harbouring the attached bacterial flora [5]. The marine bacterial community compositions and their exoenzyme activity can change dramatically during a phytoplankton bloom [6]. Successions of cultivable bacterial phenotypes which were demonstrated in near shore waters of Beaufort Sea according to season and geography in response to algal blooms showed that all isolated bacterial strains tend to differ significantly from the nonblooming marine environments [7]. The associated bacterial population and its diversity are controlled by algae to a certain extent by mediating the production of antibiotics [8], or the secretion of hydroxyl radicles toxic to bacteria [9]. Conversely, the bioactive substance produced by the associated bacteria will in turn affect the algal bloom dynamics [10]. The present paper focuses on the cultivable bacterial community associated with Chattonella marina bloom and the extracellular enzyme production potential of these associated bacteria. The result 


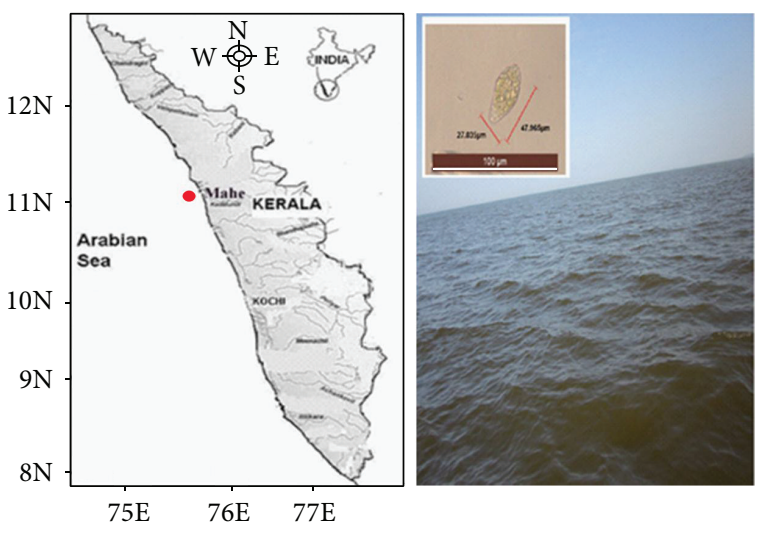

FIGURE 1: Location of Chattonella marina bloom and water discolouration during the bloom (inset: Chattonella marina).

of this study has given an insight into the important bacterial genera which may play a potential role in the Chattonella marina bloom regulation as well as in the probable role of extracellular enzymes produced by the bacteria in bloom control.

\section{Materials and Methods}

2.1. Study Area and Sample Collection. A massive bloom of Chattonella marina (Subrahmanyan) Hara \& Chihara was observed off Mahe $\left(11^{\circ} 42^{\prime} 18 \mathrm{~N}, 75^{\circ} 32^{\prime} 36 \mathrm{E}\right)$ (Figure 1), a selected station as part of the harmful algal bloom monitoring programme of the Ministry of Earth Sciences, Government of India. For the bacteriological analysis, the samples of Chattonella marina bloom and additional reference samples from region outside the vicinity of the blooming area were collected periodically on 27 and 29 October and 1 November 2011 and were aseptically transferred into sterile polyethylene bottles.

2.2. Isolation of Associated Bacterial Strains. The bloom samples were filtered through sterile vacuum filtration unit. Algal cells were harvested by centrifugations and were sonicated by using an ultrasonicator (Sonics \& Materials Inc., USA) in order to detach the associated bacterial cells in the algae. Surface plating for cultivable fraction of bacteria was carried out on ZoBell's Marine Agar 2216e medium (HiMedia, India) after suitable dilutions of bloom and the nonbloom reference samples and the plates were subsequently incubated at $28 \pm$ $2^{\circ} \mathrm{C}$ for a period of 48-72 hours. The number of colony forming units (CFU) was counted and expressed as CFU mL $\mathrm{m}^{-1}$ of water sample and purified strains were identified up to generic level by conventional biochemical test [11].

2.3. Screening of Exoenzymes. The potential of the algae associated bacteria to produce extracellular enzymes was determined by agar diffusion method [12]. Nutrient agar media of $\mathrm{pH} 7.2$ in seawater were supplemented with the respective substrates, $1 \%$ gelatin for protease test, $1 \%$ tributyrin for lipase, $0.5 \%$ tannic acid for ligninase, $0.5 \%$ starch for amylase, $0.5 \%$ carboxy methyl cellulose for cellulose, $0.01 \%$ phenolphthalein diphosphate for phosphatase test, and 1.5\% sodium alginate for alginase test. When tested with respective reagents, the cultures that showed colouration or clearance zone were considered as positive colonies. Protease activity was determined by development of a clearance zone around the colonies after having been treated with 15\% mercuric chloride solution. The lipase as well as lignin positive colonies showed a clearance zone after $2-5$ days of incubation. The amylase positive colonies showed a clearance zone when treated with Lugol's iodine solution. The cellulase positive colonies showed a clearance zone in a bright red background on CMC agar when flooded with Congo red dye $(1 \mathrm{mg} / \mathrm{mL})$. Phosphatase activity was determined by the development of pink colouration around the colonies on phenolphthalein agar when subjected to ammonia fumes. Sodium alginate degradation by alginate lyases was shown as a clearance zone when treated with $10 \%(\mathrm{w} / \mathrm{v})$ cetylpyridinium chloride.

2.4. Measurement of Surface Water Characteristics. For the taxonomic identification of the microalgae, 10 liters of bloom sample was kept in shade/darkness for 30 minutes to settle the motile raphidophyte cells. The supernatant was poured off and the "thick" mat of Chattonella cells was transferred into clean polyethylene bottles. For quantitative analysis a few drops of Lugol's iodine were added as preservative. Live samples were also collected for qualitative studies as Chattonella spp. are susceptible to preservative [13]. The identification was made on the basis of a standard taxonomic key [14].

In situ measurement of different hydrographic variables such as temperature, salinity, and $\mathrm{pH}$ was done with standard instruments. Chlorophyll $a(\mathrm{Chl} a)$ nutrients (nitrite, nitrate, phosphate, and silicate) were analysed [15] with the help of a Hitachi U-3900 UV visible spectrophotometer. Dissolved oxygen and primary productivity were measured by Winkler's method.

\section{Results and Discussion}

3.1. Comparative THB Load in Bloom and Nonbloom Sample. Periodic sampling of Chattonella marina bloom revealed an increase in the total heterotrophic bacterial (THB) load during the decline phase of the bloom when compared to the nonbloom sample. THB was recorded as $10.9 \times$ $10^{4} \mathrm{cfu} \mathrm{\textrm {mL } ^ { - 1 }}$ in the first day of sampling. On the second and third samplings, THB were $27.5 \times 10^{4} \mathrm{cfu} \mathrm{mL}^{-1}$ and $175 \times$ $10^{4} \mathrm{cfu} \mathrm{mL}^{-1}$, respectively, whereas the THB in the nonbloom samples were $1.2 \times 10^{4} \mathrm{cfu} \mathrm{mL}^{-1}, 3.2 \times 10^{4} \mathrm{cfu} \mathrm{mL}^{-1}$, and $4.9 \times 10^{4} \mathrm{cfu} \mathrm{mL}^{-1}$ in the first, second, and third samplings, respectively (Figure 2 ). The variation in total heterotrophic bacterial load between bloom and nonbloom was significant in the periodic days of sampling $(P<0.001$, one-way ANOVA). A peak in associated bacterial population or biomass has been reported during or near the death phase of an algal bloom in the Xiamen Sea of China [16]. The gradual increase in the total heterotrophic bacterial load in the bloom area showed the probable role of bacteria in bloom crash. 


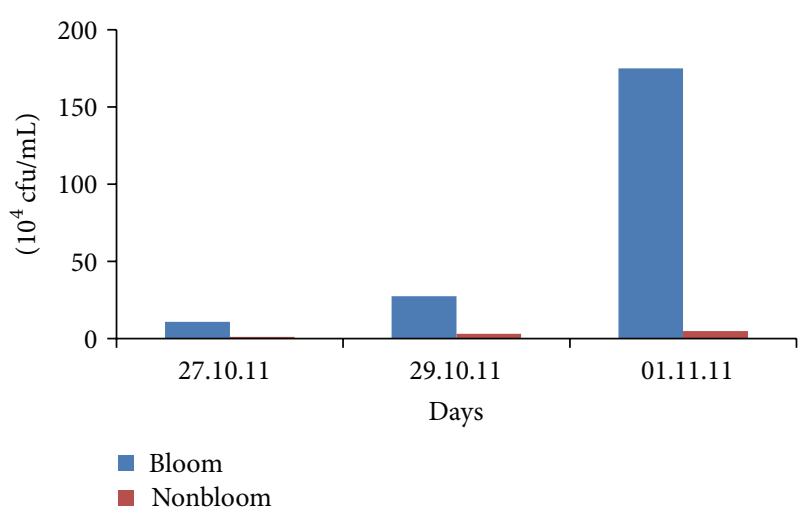

FIgURE 2: Total heterotrophic bacterial (THB) count during Chattonella marina bloom and nonbloom sample.

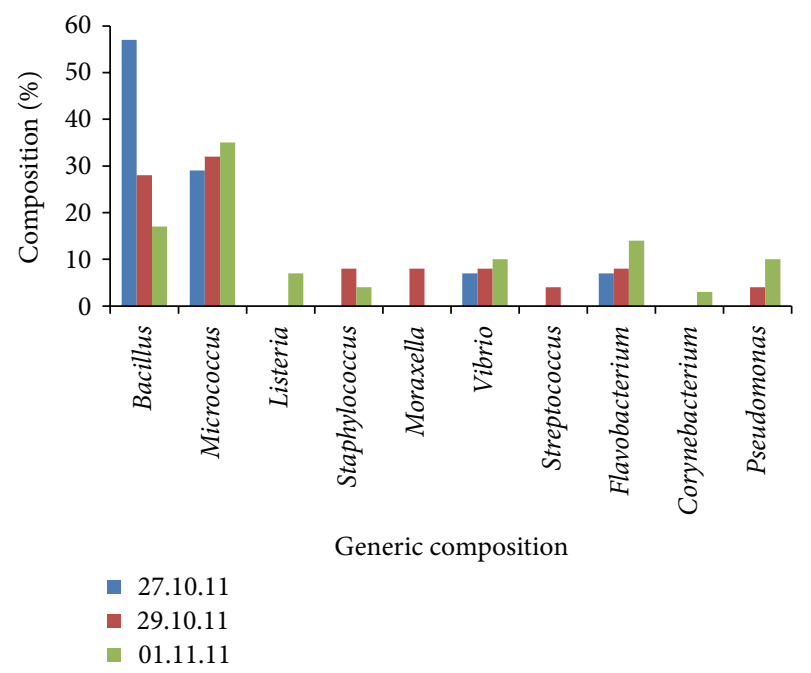

FIGURE 3: Generic composition of heterotrophic bacteria associated with Chattonella marina bloom.

3.2. Comparative Generic Composition in Bloom and Nonbloom Sample. Chattonella marina bloom which showed a decline in the planktonic cell count in the successive samplings harboured several bacterial genera in which Micrococcus and Bacillus were the predominant ones followed by Flavobacterium, Vibrio, Listeria, Moraxella, Staphylococcus, Streptococcus, Corynebacterium, and Pseudomonas (Figure 3). Flavobacterium, Vibrio, and Pseudomonas spp., which were recorded as bloom associated bacteria [17-19], were also found to be associated with C. marina bloom. It has been found that, on periodic sampling, the associated bacterial genera showed considerable difference in cell abundance. As bloom intensity decreased, the abundance of Micrococcus, Pseudomonas, and Vibrio spp. was observed. Such an increase in specific bloom associated bacteria has been reported $[17,19]$. The associated bacterial genera influence the bloom dynamics. Micrococcus, Vibrio, Pseudomonas, Flavobacterium, and Bacillus spp. abundant in this raphidophycean bloom were reported to have algicidal activity on several other algal blooms recorded elsewhere

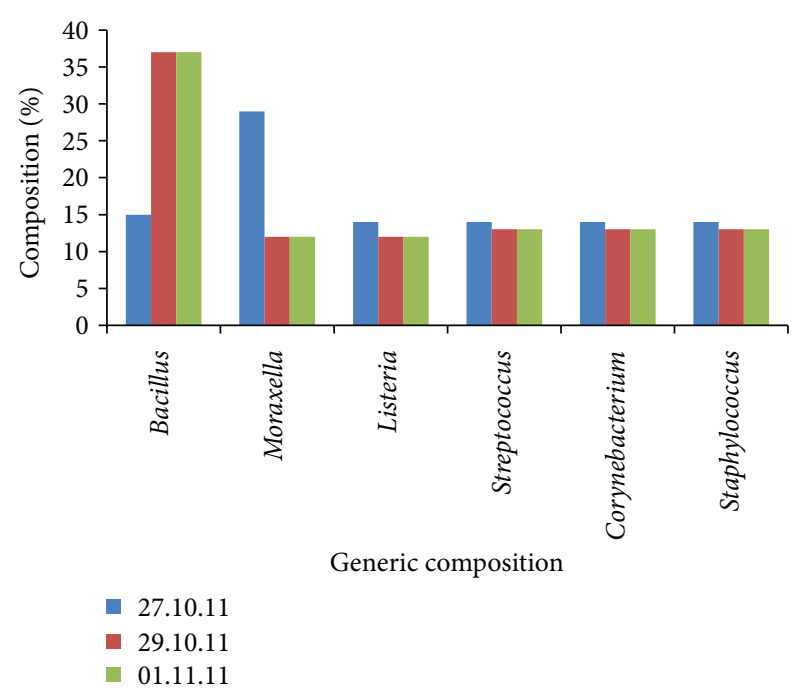

FIGURE 4: Generic composition of heterotrophic bacteria in the nonbloom samples.

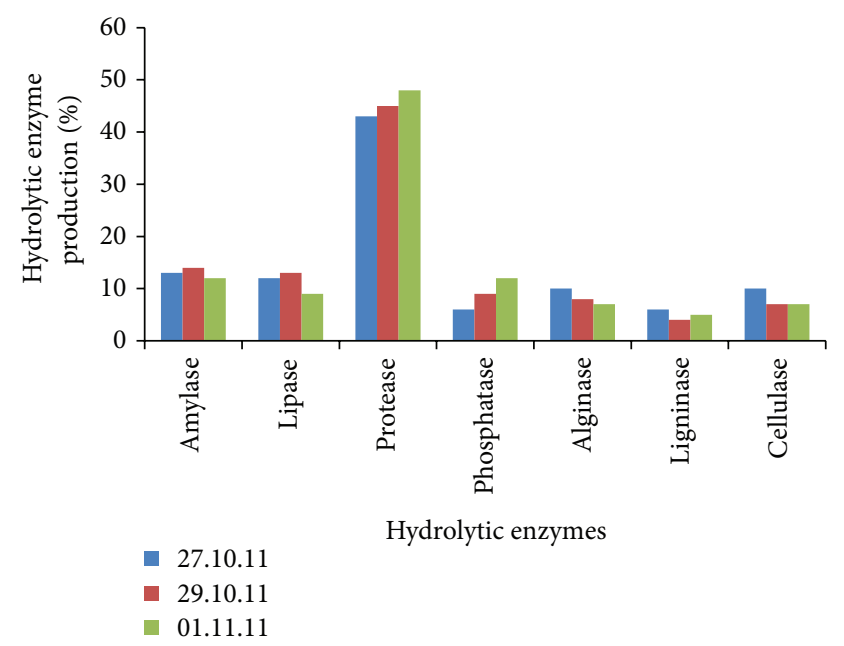

FIGURE 5: Hydrolytic enzyme production of bacteria associated with Chattonella marina bloom.

[19-22]. In the present study also, the dominance of specific bacterial flora during the decline phase of the algal bloom was observed suggesting the probable role of bacteria in regulation of algal blooms. Such a remarkable variation in the generic diversity as well as in the percentage composition of bacterial genera was not observed in the nonbloom area. (Figure 4). The associated bacteria may exert their activity either by direct contact with the cell or by their extracellular metabolite production.

3.3. Comparative Production Potential of Extracellular Enzyme of Bacteria from Bloom and Nonbloom Sample. The bacteria isolated from the samples were screened for their ability to produce extracellular enzymes. There was considerable difference in the ability of the bacteria to produce various extracellular enzymes (Figures 5 and 6). The percentage of 
TABLE 1: Surface water characteristics in the coastal waters off Mahe during Chattonella marina bloom.

\begin{tabular}{|c|c|c|c|c|}
\hline \multirow{2}{*}{ Parameters } & \multicolumn{3}{|c|}{ Sampling period } & \multirow{2}{*}{ Mean } \\
\hline & 27.10 .2011 & 29.10 .2011 & 01.11.2011 & \\
\hline Sea water temperature $\left({ }^{\circ} \mathrm{C}\right)$ & 25 & 26 & 27 & 26 \\
\hline Salinity (psu) & 30 & 30 & 28 & 29.33 \\
\hline $\mathrm{pH}$ & 7.9 & 8 & 7.7 & 7.86 \\
\hline $\mathrm{DO}\left(\mathrm{mg} \mathrm{L}^{-1}\right)$ & 4.4 & 4.8 & 5.2 & 4.83 \\
\hline Phosphate $\left(\mu \mathrm{ML}^{-1}\right)$ & 0.51 & 0.56 & 0.49 & 0.52 \\
\hline Nitrite $\left(\mu \mathrm{ML}^{-1}\right)$ & 0.13 & 0.09 & 0.14 & 0.12 \\
\hline Nitrate $\left(\mu \mathrm{M} \mathrm{L}^{-1}\right)$ & 12.54 & 7.54 & 6.99 & 9.02 \\
\hline Silicate $\left(\mu \mathrm{M} \mathrm{L}^{-1}\right)$ & 2.38 & 2.58 & 3.47 & 2.81 \\
\hline Chlorophyll $a\left(\mu \mathrm{g} \mathrm{L}^{-1}\right)$ & 10.89 & 9.83 & 6.69 & 9.13 \\
\hline Primary productivity $\left(\mathrm{gC} / \mathrm{m}^{3} /\right.$ day $)$ & 1.94 & 1.2 & 4.24 & 2.46 \\
\hline
\end{tabular}

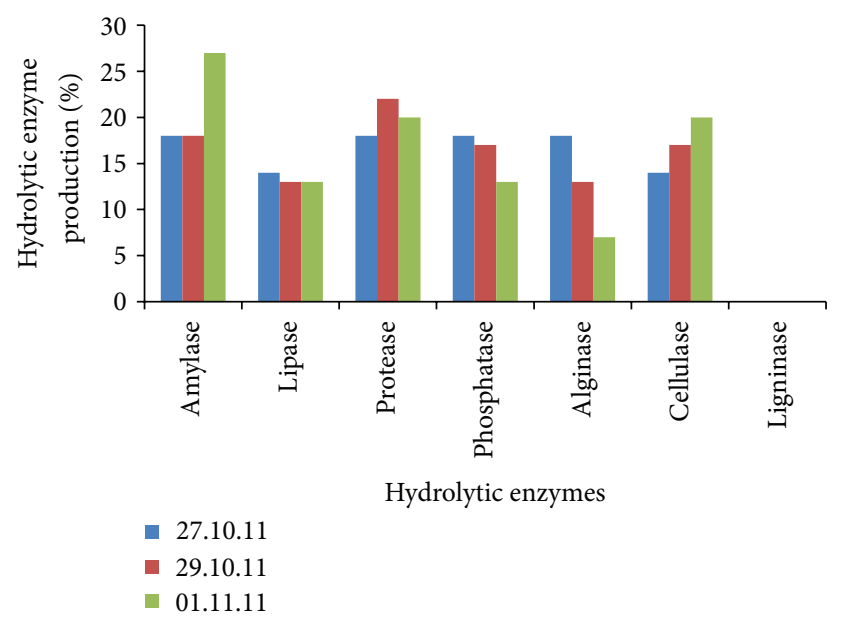

FIGURE 6: Hydrolytic enzyme production of heterotrophic bacteria in the nonbloom samples.

protease enzyme producers was more in the bloom sample. Extracellular proteases are known to possess algicidal activity $[19,23]$. The percentages of bacteria which were able to produce protease during the sampling period were $43 \%, 45 \%$, and $48 \%$ in the first, second, and third days of sampling, respectively. Statistically there is significance in the protease producing bacteria in bloom and nonbloom in the periodic days of sampling $(P<0.001$, one-way ANOVA). The results suggest that at least some algicidal bacteria impose their algicidal effect by extracellular proteases production.

3.4. Surface Water Characteristics during the Bloom. The physicochemical characteristics showed a remarkable variation in the different phases of Chattonella marina bloom (Table 1). On 27 October 2011, Chattonella marina bloom was monospecific, with a recorded cell abundance of $4.5 \times$ $10^{6}$ cells $^{-1}$ with chlorophyll $a$ concentration of $10.89 \mu \mathrm{gl}^{-1}$. On the second day of observation, the cell abundance of Chattonella marina receded to $4 \times 10^{6}$ cells $^{-1}$. A few species of diatoms like Coscinodiscus asteromphalus Ehrenberg, Coscinodiscus radiatus Ehrenberg, and Odontella aurita
(Lyngbye) C.Agardh were also observed. Chlorophyll $a$ concentration also receded to $9.83 \mu \mathrm{gl}^{-1}$. On the last day of observation, 1 November 2011, the standing crop of Chattonella marina again receded to $3.8 \times 10^{5}$ cells $^{-1}$ with increased abundance of diatoms and dinoflagellates like

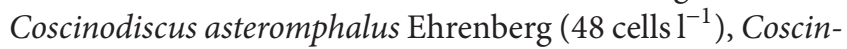
odiscus radiatus Ehrenberg $\left(18\right.$ cells $\left.^{-1}\right)$, Cylindrotheca gracilis (Brébisson ex Kützing) Grunow (26 cells $1^{-1}$ ), Pleurosigma aestuarii (Brébisson ex Kützing) W.Smith $\left(18\right.$ cells $^{-1}$ ), Ceratoneis closterium Ehrenberg $\left(10\right.$ cells $\left.\mathrm{l}^{-1}\right)$, Hantzschia marina (Donkin) Grunow (8 cells $\mathrm{l}^{-1}$ ), Odontella aurita (Lyngbye) C.Agardh (12 cells $\left.{ }^{-1}\right)$, Chaetoceros decipiens Cleve (12 cells $1^{-1}$ ), and Campylodiscus ecclesianus Greville $\left(8\right.$ cells $^{-1}$ ) and lower number of dinoflagellates such as Prorocentrum gracile Schütt $\left(7\right.$ cells $\left.^{-1}\right)$ and Tripos furca (Ehrenberg) F.Gómez $\left(4\right.$ cells $\left.^{-1}\right)$. The chlorophyll $a$ concentration also receded to $6.69 \mu \mathrm{gl}^{-1}$. So in the periodic days of sampling, it could be found out that bloom showed a gradual decrease in cell abundance with chlorophyll $a$ concentration. From the first day of periodic sampling a gradual increase in temperature and decrease in salinity and $\mathrm{pH}$ were observed. It was reported that the optimum temperature and salinity for Chattonella marina in the laboratory culture were $25^{\circ} \mathrm{C}$ and $30 \mathrm{psu}$, respectively [24]. However, there were several reports which showed variations in optimum conditions for the Chattonella marina blooming [25]. In the present study the intensity of bloom was high on the first day where the temperature was $25^{\circ} \mathrm{C}$ and the bloom intensity receded as the temperature increased in the following days. The blooming of Chattonella marina prefers a nitrogen-rich condition especially the nitrate [1]. In the present investigation it is also noticed that the concentration of nitrate was high in the first day and the gradual receding of bloom occurred as the nitrate concentration decreased in the following days.

\section{Conclusion}

Algal blooms are a potentially significant phenomenon, nowadays with more implicated threats to human health and environment, including harmful effects on natural and cultured resources, tourism, and ecosystems all over the 
world. The bacteria which are having the algicidal effect can act as biological control agents to algal bloom with the least adverse effect on the ecosystem. Previous studies have revealed the existence of such bacteria in the phytoplankton bloom and the increase of their abundance following the bloom crash. The present study also supported this finding where, as the Chattonella marina bloom gets its decline stage, the bacterial genera Micrococcus, Flavobacterium, Vibrio, and Pseudomonas specifically associated with algal bloom showed a gradual increase. Extracellular protease produced by associated bacteria was found to have algicidal activity $[19,23]$. Results of the present study also supports the above observation as the percentage of bacteria that are capable of elaborating extracellular protease was found to be increased in the declining phase of the bloom. Micrococcus, Flavobacterium, Vibrio, and Pseudomonas spp. which showed a gradual increase in abundance in the successive stages of Chattonella marina bloom, were also potent in protease production, which indicated their probable role in algicidal activity either by direct contact or by protease production.

Bacterial dynamics during a phytoplankton bloom may lead to a shift in the community composition from the beginning to the decline phase [6]. The growth conditions are not uniform for different groups of bacteria, and the influence of biotic and abiotic factors promotes successive changes in the community composition [26]. Phytoplankton blooms increase the particulate and dissolved organic matter in the water resulting in the increased bacterial production and ectoenzyme activity $[27,28]$. Thus it is probable that bacterial dynamics during a phytoplankton bloom reflect a succession where changes in the organic environment continuously support the growth of adapting species. Functional changes in the bacterial community were also indicated by marked increases in growth and enzyme activity of bacteria [6]. Hence, from the present study, it can be concluded that there is a succession of bacteria during Chattonella marina bloom and the extracellular enzymes, especially proteases, produced by these bacteria play a crucial role in bloom termination along with the changes in key physicochemical factors like temperature, salinity, and nitrate. The bacterial genera associated with this bloom, Micrococcus, Flavobacterium, Vibrio, and Pseudomonas, have high potential for protease enzyme production and may regulate the successive stages of Chattonella marina bloom, from peak to decline. However, further studies are necessary to understand the role of individual bacteria and the exoenzymes in bloom regulation.

\section{Conflict of Interests}

The authors declare that there is no conflict of interests regarding the publication of this paper.

\section{Acknowledgment}

The authors gratefully acknowledge the financial assistance from the Centre for Marine Living Resource and Ecology, Ministry of Earth Sciences, Government of India.

\section{References}

[1] Z. Wang, M. Yuan, Y. Liang, and S. Lu, "Effects of temperature and organic and inorganic nutrients on the growth of Chattonella marina (Raphidophyceae) from the Daya Bay, South China Sea," Acta Oceanologica Sinica, vol. 30, no. 3, pp. 124-131, 2011.

[2] R. Jugnu and V. Kripa, "Effect of Chattonella marina [(Subrahmanyan) hara et chihara 1982] bloom on the coastal fishery resources along Kerala coast, India," Indian Journal of Marine Sciences, vol. 38, no. 1, pp. 77-88, 2009.

[3] M. G. Sanilkumar, A. M. Thomas, K. C. Vijayalakshmi, A. A. Mohamed Hatha, and A. V. Saramma, "Chattonella marina bloom in the coastal sea off Mahe, Southwest India," Current Science, vol. 103, no. 6, pp. 624-626, 2012.

[4] M. Endo, Y. Onoue, and A. Kuroki, "Neurotoxin-induced cardiac disorder and its role in the death of fish exposed to Chattonella marina," Marine Biology, vol. 112, no. 3, pp. 371-376, 1992.

[5] S. Franca, S. Viegas, V. Mascarenhas, L. Pinto, and G. J. Doucette, "Prokaryotes in association with a toxic Alexandrium lusitanicum in culture," in Harmful Marine Algal Blooms, P. Lassus, G. Arzul, E. Erard, P. Gentien, and C. Marcaillou, Eds., pp. 44-51, Lavoisier, Paris, France, 1995.

[6] L. Riemann, G. F. Steward, and F. Azam, "Dynamics of bacterial community composition and activity during a mesocosm diatom bloom," Applied and Environmental Microbiology, vol. 66, no. 2, pp. 578-587, 2000.

[7] T. R. Kaneko, M. I. Krichevsky, and M. R. Atlas, "Numerical taxonomy of bacteria from the Beaufort Sea," Journal of General Microbiology, vol. 110, no. 1, pp. 111-125, 1979.

[8] C. G. Trick, R. J. Andersen, and P. J. Harrison, "Environmental factors influencing the production of an antibacterial metabolite from a marine dinoflagellate, Prorocentrum minimum," Canadian Journal of Fisheries and Aquatic Sciences, vol. 41, no. 3, pp. 423-432, 1984.

[9] T. Oda, T. Akaike, K. Sato et al., "Hydroxyl radical generation by red tide algae," Archives of Biochemistry and Biophysics, vol. 294, no. 1, pp. 38-43, 1992.

[10] H. H. Seliger, "Red tide mechanisms: spatial and temporal scales," in Toxic Phytoplankton Blooms in the Sea, T. J. Smayda and Y. Shimizu, Eds., pp. 819-824, Elsevier, New York, NY, USA, 1993.

[11] R. E. Buchnan and N. E. Gibbons, Bergey's Manual of Determinative Bacteriology, Williams \& Wilkins, Baltimore, Md, USA, 8th edition, 1974.

[12] P. Gerhardt, R. G. E. Murray, R. N. Costilov et al., Manual Methods for General Bacteriology, American Society for Microbiology, Washington, DC, USA, 1981.

[13] J. Throndsen, “The planktonic marine flagellates," in Identifying Marine Phytoplankton, C. R. Tomas, Ed., pp. 591-729, Academic Press, New York, NY, USA, 1997.

[14] C. R. Tomas, Identifying Marine Diatoms and Dinoflagellates, Academic Press, New York, NY, USA, 1997.

[15] J. D. H. Strickland and T. R. Parsons, A Practical Handbook of Seawater Analysis, Fisheries Research Board of Canada, 1972.

[16] C. Yang, Y. Li, Y. Zhou, W. Zheng, Y. Tian, and T. Zheng, "Bacterial community dynamics during a bloom caused by Akashiwo sanguinea in the Xiamen sea area, China," Harmful Algae, vol. 20, pp. 132-141, 2012. 
[17] X. Mayali and F. Azam, "Algicidal bacteria in the sea and their impact on algal blooms," Journal of Eukaryotic Microbiology, vol. 51, no. 2, pp. 139-144, 2004.

[18] C. E. Hare, E. Demir, K. J. Coyne, S. Craig Cary, D. L. Kirchman, and D. A. Hutchins, "A bacterium that inhibits the growth of Pfiesteria piscicida and other dinoflagellates," Harmful Algae, vol. 4, no. 2, pp. 221-234, 2005.

[19] A. M. Thomas, M. G. Sanilkumar, K. C. Vijayalakshmi, A. A. M. Hatha, and A. V. Saramma, "Proboscia alata (Brightwell) Sandström bloom in the coastal waters off Bekal, Southwest India," Current Science, vol. 106, no. 12, pp. 1643-1646, 2014.

[20] M.-J. Kim, S.-Y. Jeong, and S.-J. Lee, "Isolation, identification, and algicidal activity of marine bacteria against Cochlodinium polykrikoides," Journal of Applied Phycology, vol. 20, no. 6, pp. 1069-1078, 2008.

[21] S. Yoshizawa, M. Wada, A. Yokota, and K. Kogure, "Vibrio sagamiensis sp. nov., luminous marine bacteria isolated from sea water," Journal of General and Applied Microbiology, vol. 56, no. 6, pp. 499-507, 2010.

[22] B. X. Wang, Y. Y. Zhou, S. J. Bai et al., "A novel marine bacterium algicidal to the toxic dinoflagellate Alexandrium tamarense," Letters in Applied Microbiology, vol. 51, no. 5, pp. 552-557, 2010.

[23] S.-O. Lee, J. Kato, N. Takiguchi et al., "Involvement of an extracellular protease in algicidal activity of the marine bacterium Pseudoalteromonas sp. strain A28," Applied and Environmental Microbiology, vol. 66, no. 10, pp. 4334-4339, 2000.

[24] J. A. Marshall and G. M. Hallegraeff, "Comparative ecophysiology of the harmful alga Chattonella marina (Raphidophyceae) from South Australian and Japanese waters," Journal of Plankton Research, vol. 21, no. 10, pp. 1809-1822, 1999.

[25] Y. Nakamura and M. M. Watanabe, "Growth characteristics of Chattonella antiqua (Raphidophyceae)," Journal of the Oceanographical Society of Japan, vol. 39, no. 3, pp. 110-114, 1983.

[26] J. Pernthaler, F.-O. Glöckner, S. Unterholzner, A. Alfreider, R. Psenner, and R. Amann, "Seasonal community and population dynamics of pelagic bacteria and archaea in a high mountain lake," Applied and Environmental Microbiology, vol. 64, no. 11, pp. 4299-4306, 1998.

[27] R. J. Chróst, "Characterization and significance of $\beta$ - glucosidase activity in lake water," Limnology \& Oceanography, vol. 34, no. 4, pp. 660-672, 1989.

[28] M. Søndergaard, P. J. L. B. Williams, G. Cauwet et al., "Net accumulation and flux of dissolved organic carbon and dissolved organic nitrogen in marine plankton communities," Limnology and Oceanography, vol. 45, no. 5, pp. 1097-1111, 2000. 

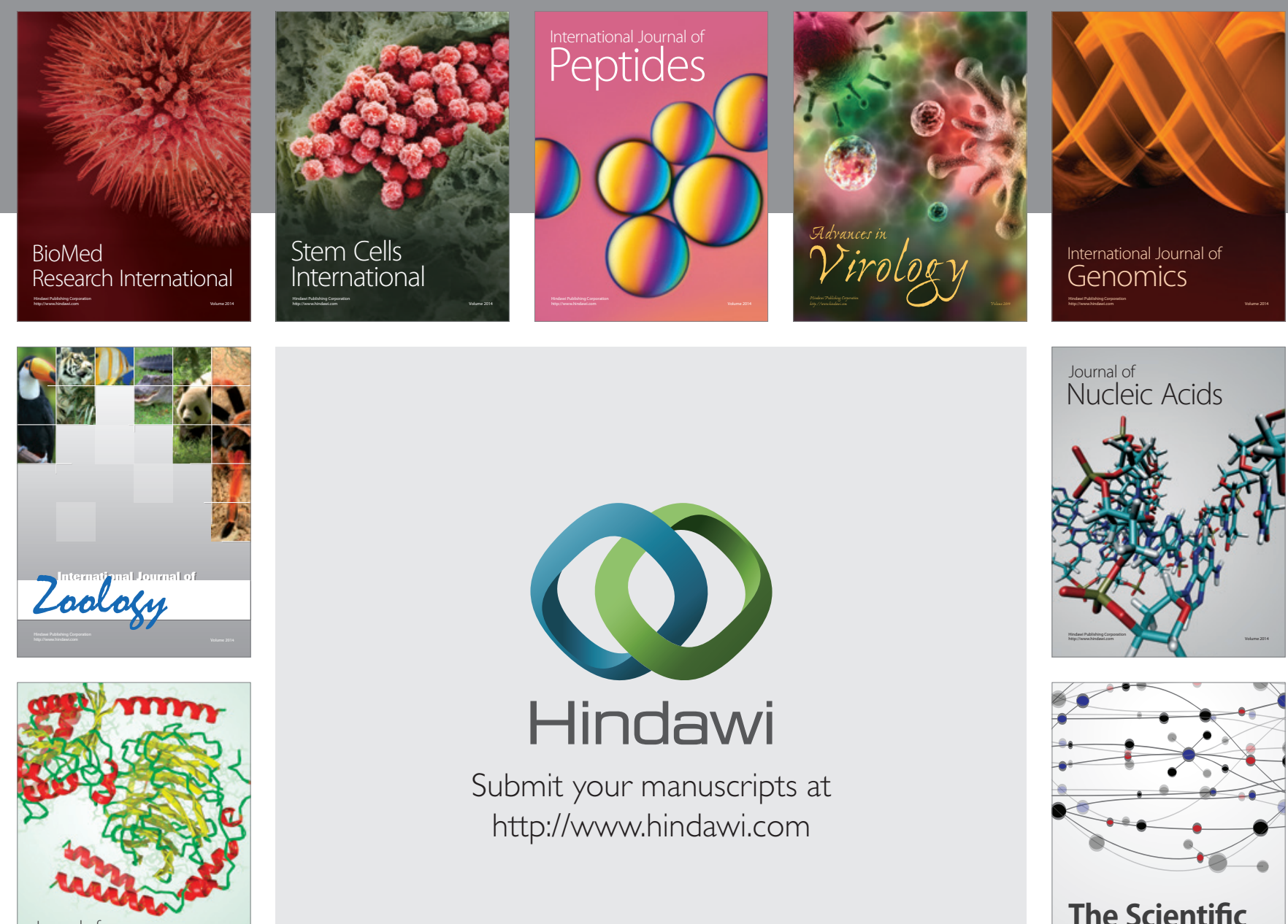

Submit your manuscripts at

http://www.hindawi.com

Journal of
Signal Transduction
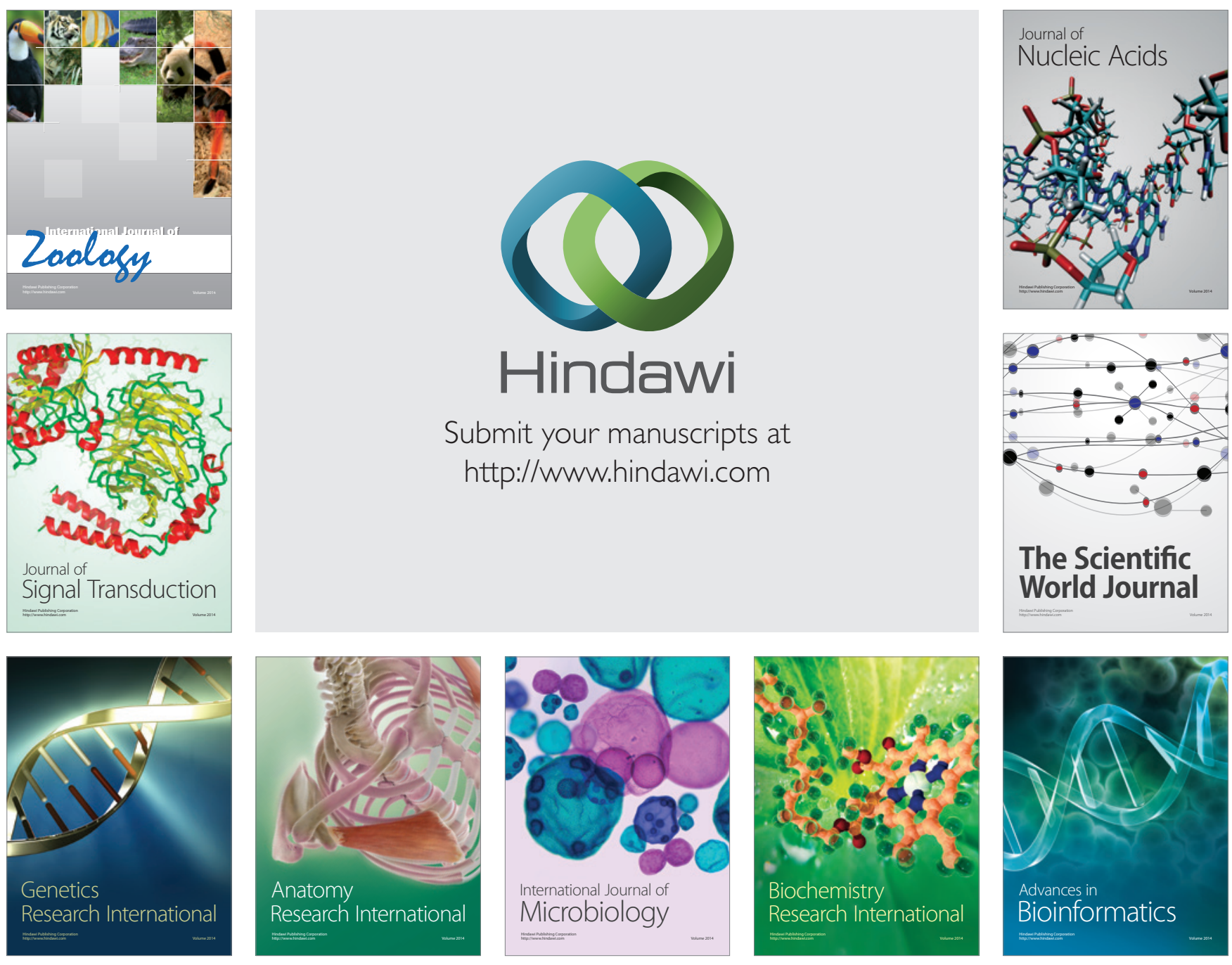

The Scientific World Journal
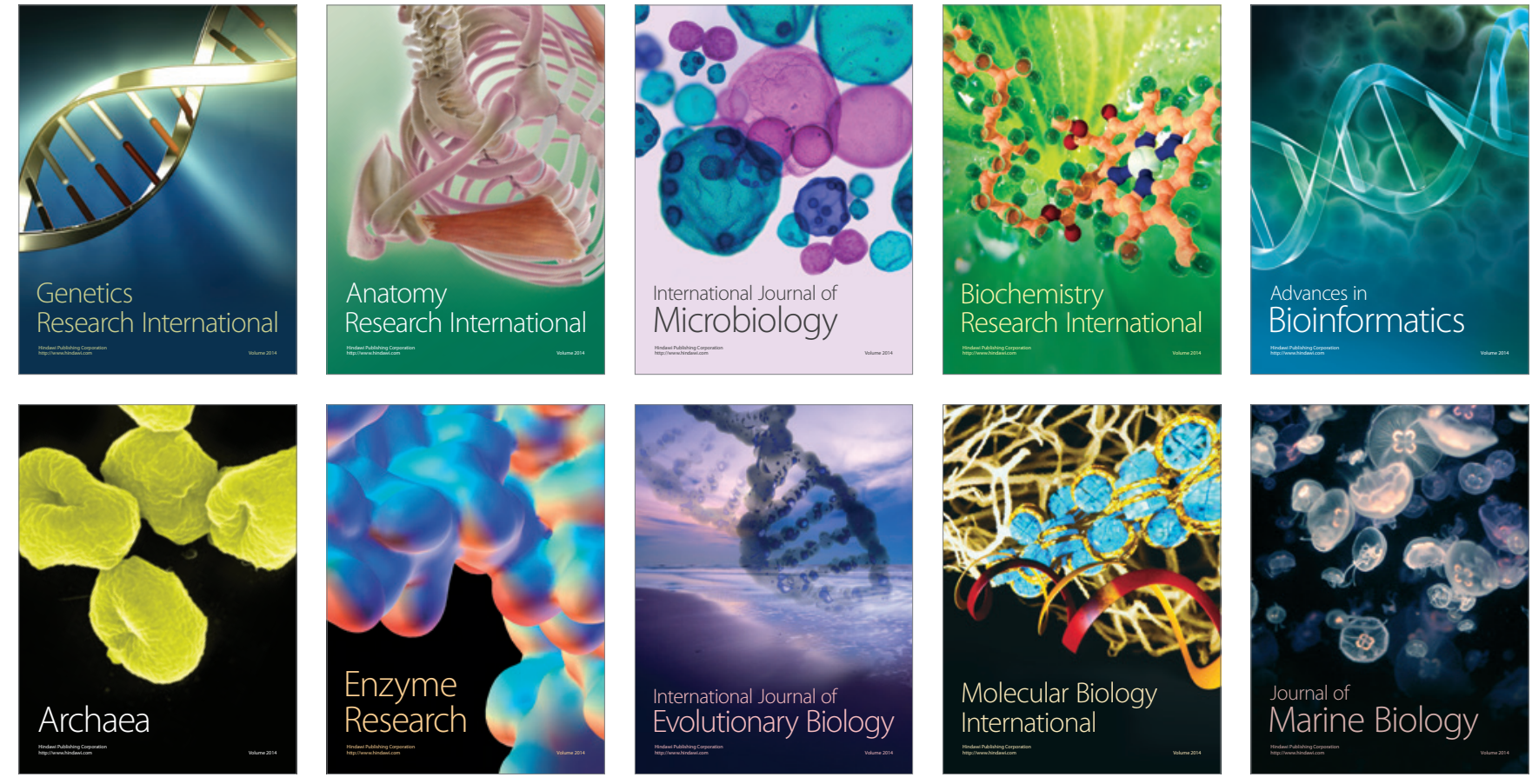